\title{
ダイオキシン類対策特別措置法及び関連法規の解説
}

\author{
通産省 環境立地局環境指導室長 大 滝 昌 平*
}

\section{Law Concerning Special Measures against Dioxin}

\section{Shohei Otaki}

Environment Protection Guidance Office,

Environment Protection and Industrial Location Bureau, MITI

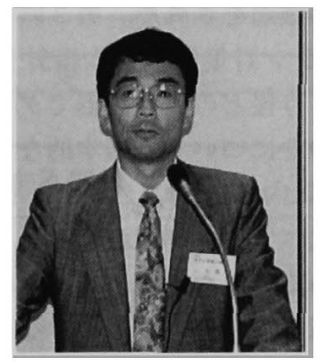

With a dioxin debacle that occurred at Tokorozawa last year, the need to regulate dioxin discharge was discussed in many sectors. As a result, the law concerning special measures against dioxins was issued in July. 1999. The law specifies dioxin compounds. which newly include coplanar poly biphenylchloride besides old two types of dioxins, namely, polychlorobenzo-p-dioxin and polychlorobenzofuran.

The paper reviews why and how the law was established.

分類 : $\mathrm{X}_{2}$ 紙パルプ産業環境一般, $\mathrm{X}_{3}$ 大気, $\mathrm{X}_{4}$ 排水

1.はじめに

タイオキシンに関する記事が新閏に載らない日はな い。例えば， $\mathrm{E}$ 製作所のタイオキシン流出問題が 6 月 7 日の新聞でも取り上げられ，今後の対策について大 きく取り扱われている。また，藤沢の引地川の近くに ある産廃処分場からタイオキシンが流れて出ているの ではないかという記事もあり，また熊谷でも噮境庁の 調査によって，かなりたくさんのタイオキシンが検出 されたという記事が出ているという具合で，タイオキ シンに对する関心は非常に高いものがある。ここでは, 昨年 7 月に成立した「タイイオキシン類対策特別措置法」 の成立の経緯と内容について述べる。

\section{"講師略歴}

1983 年通産省入省 1998 年環境指導室長

"*本稿はセミナー講演の録音収録より，会誌編集委員 会にて要約した。

\section{2. ダイオキシン類対策特別措置法成立の背景}

昨年 7 月に成立した「タイオキシン類対策特別措置 法」では, 対象となる「タイイオキシン類」を従来の夕 イオキシン, すなはち、ポリ塩化ジベンゾーパラージオ キシン, ポリ塩化ジベンゾフランの 2 種類に加えて, コプラナーPCB，いわゆる PCBではあるがある特定 の性状を持つ異性体を含めて定義している。従って従 来のタイオキシンよりも広い範囲に対して規制が掛か っているのである。

タイオキシン類対策特別措置法が作られる契機とな ったのは, 昨年所沢市で高い值のダイオキシンが検出 されたという問題であった。この問題をテレビ番組が 大きく取り上げたということもあって, 社会問題と認 識されるようになった。この問題に対応するため昨年 の 2 月にダイオキシン対策関係閣僚会議が作られ, 現 在までに 6 回の会合を開いている。

1 回目の会合では, 前述の所沢市のタイオキシン問 題についてどのような対応を取るかという議論がされ た。これを契機として，タイオキシンについて替制を 
する必要があるのではないかという論議が急速に大き くなっていったのである。

一方, テレビが先ほどの問題を取り上げる前に，公 明党が参議院にタイオキシン類対策特別措置法案とい うものを提出した。また昨年 2 月に, 民主党も同様の 法案を出している。このような法案提出の動きは, こ のころからあったわけだが，前述の事件を契機に閣僚 会議が開かれ，その閣僚会議の中でもその対策の必要 性について議論をされた。第 3 回目の会合において, 「ダイオキシン対策推進基本指針」を決めている。こ の中には，今後どのような形でタイオキシン対策を進 めていくのかについての基本的な考えを述べた上で, 「今後 4 年以内に全国のタイオキシン類棇排出量を平 成 9 年に比べて約 9 割削减する」という目標が明確に 書かれている。またこのような目標を実現するために， 種々の対策を取らなければいけないということを具体 的に述べている。

その後, 5 月 20 日に共産党がタイオキシン類緊急措 置法案を提出した。このような動きを受けて,6月に なって与党間でも法案の検討が始められ, 昨年 7 月 12 日議員立法の形で国会に提出され, 3 日後に「ダイ オキシン類対策特別措置法」が衆議院の本会議で可決 ・成立した。この法律は, 若干違っている部分がある ものの水質污濁防止法と大気污染防止法の関係部分を そのまま持ってきたような形になっており，その意味 で従来规制の体系の形を借りた法律と言うことができ る(図 1)。

\section{3. ダイオキシン類の特質}

先のタイオキシン对策推進基本指針の中においては， タイオキシン類の排出削滅对策を推進するために，い まどれぐらいのタイオキシンが外に出されているのか を各発生源別に目録を作ることになっている。これを われわれは「排出インベントリー」と呼んでいて，表 1 にその内容を示す。平成 9 年には, 全国 6,330 6,370 gのタイオキシンか，また平成 10 年には 2,900 一 $2,940 \mathrm{~g}$ のタイオキシンが排出されたと考えられてい る。

製紙業においては, ボイラー関係で $1.7 \mathrm{~g}$, 污泥の 焼却関係で $2.8 \mathrm{~g}$ ，これは大気関係だが，哂・クラフ 卜関係で $0.4 \sim 0.1 \mathrm{~g}$ という形で水でも大気でも若干 ではあるが排出している。

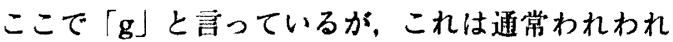
が使っている $\mathrm{g}$ という単位と若干意味が異なり，「毒 性当量」という形に圈き換えた数字である。先ほどポ リ塩化ジベンソフラン, ポリ掹化ジベンソーパラージオ
キシンという二つの, 旧来いわれているタイオキシン とコプラナーPCB があると述べたが，この三つの物 質は種々の異性体を持つ。一番毒性が強いものは，ジ ベンゾーパラージオキシン（2378）で，この毒性を 1 と したときに，他の異性体がどのような毒性を持ってい るのかを係数で表し，おのおのの異性体毎の量に係数 を掛けて毒性の強さに置きなおした数字を作っている。 これをわれわれは「毒性当量」と呼んでいて, 通常 TEQ という文字を後ろにつけて $\mathrm{g}-\mathrm{TEQ}$ という形で表して いる。したがって, 今後は TEQ という言葉は省くが, 以後ダイオキシンの関係でグラム, またピコグラムと いう場合はすべて「毒性当量」と認識していただきた い。

これまでは総量の議論なのでグラムという単位を使 用したが、今後の議論で出てくる単位はピコグラム， ナノクラムという若干耳慣れない言葉である。ピコグ ラムは 10 のマイナス 12 乗の数字であり, 1 ピコグラ ム/lはどのぐらいの䥄度になるのかといえば，東京 ドームの中に純水をいっばい詰めてその中に角砂糖を 1 個落としたときの濃度がこれに当たる。いかに薄い かが分かるかと思うし，また逆にそのようなレべルの タイオキシン類が問題になるということは，いかにタ イオキシンが高い毒性を持っているかということを感 じて欲しいと思う。

つぎに各国のタイオキシンの排出量について述べる。 アメリカでは $1,026 \sim 7,541 \mathrm{~g}$ (1995 年推定值) とさ れている。またドイッでは $334 \mathrm{~g}$ ，オランタでは 484 $\mathrm{g}$ ，英国では 560〜1,064 g ということで，このような ドイッ，オランダ，英国などの数字に比べて，日本の $2,900 \mathrm{~g}$ という数字は必ずしも小さくなく，むしろ大 きい方である。また米国の $1,026 〜 7,541 \mathrm{~g}$ に比べて も，かなり似たような数字になっているのでダイオキ シンに対して，しっかりした施策を取って行かなけれ ばならない。

しかしタイオキシンは確かに毒性が強いものであり， 無くするに越したことはないし，無くす努力をすべき だと思うが，そのための对策については，その費用ま たは効果も勘案しつつ進めて行くことが重要だろう。 タイオキシンはインベントリー（表 1) にあるように タバコの火からも出ている。また，昔はタイオキシン がなかったかというと，少ない量ではあるが自然界の 中でタイオキシンが作られるということがある。たと えば山火事が起きるとタイオキシンが発生することは よく知られている事実である。確かに現在われわれが 作り出しているほど高濃度のものを出しているわけで はないが，自然界の中には微量ではあるがダイオキシ 
(第 2 条)

\begin{tabular}{|c|c|c|c|}
\hline 対 & $\begin{array}{l}\text { ダ } \\
\text { イ }\end{array}$ & ポリ塩化ジベンゾフラン & $\begin{array}{l}\text { 臭素系ダイオキシンは、 } \\
\text { 検討事項。 }\end{array}$ \\
\hline & $\begin{array}{l}キ \\
シ\end{array}$ & ポリ塩化ジベンソーパラージオキシン & \\
\hline & 類 & コプラナーポリ塩化ビフェニル & \\
\hline
\end{tabular}

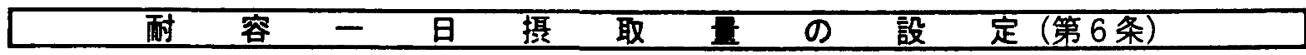

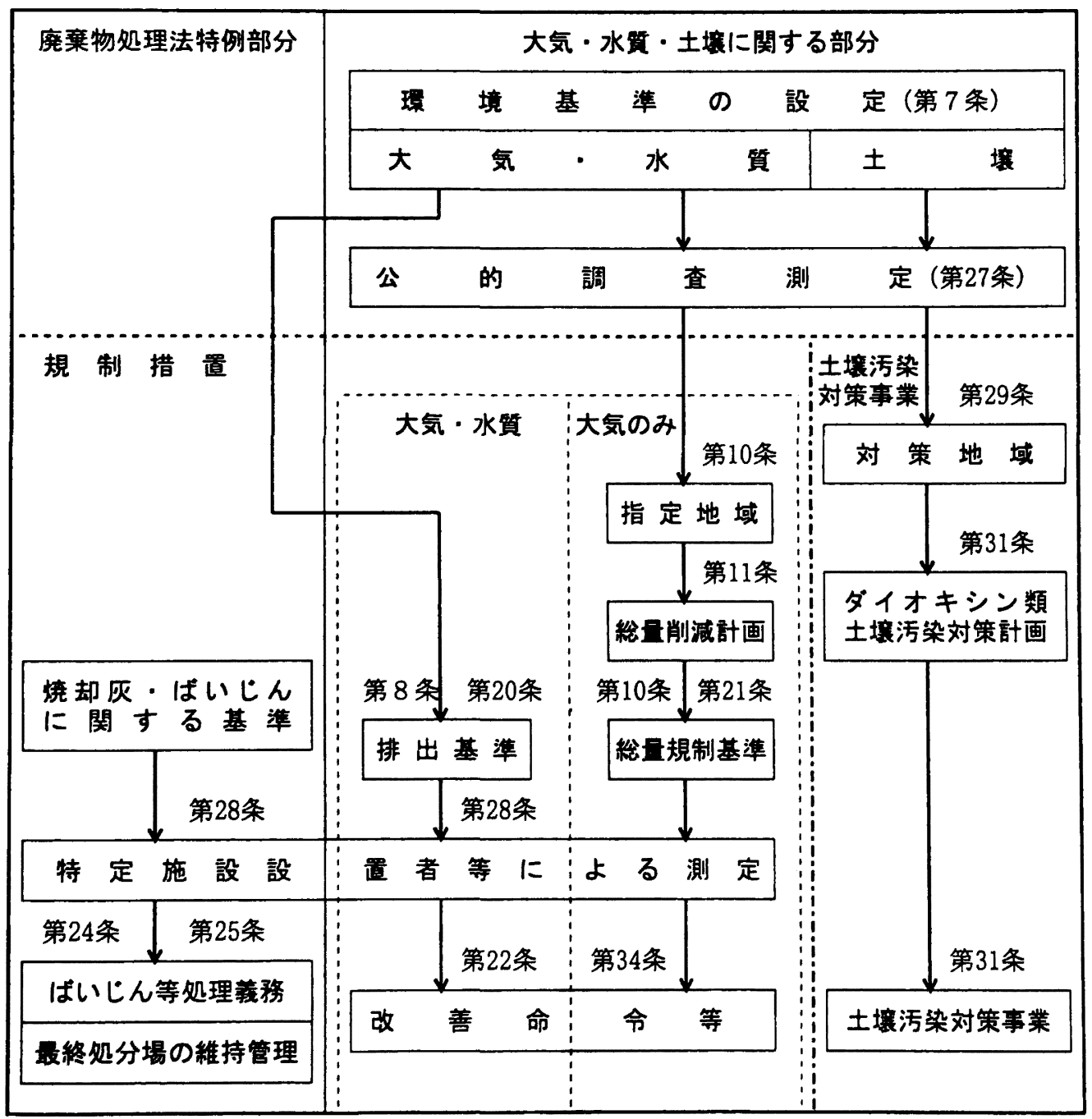

図 1 タイオキシン類対策特別措置法 


\begin{tabular}{lll} 
大 滰 昌平 \\
\hline
\end{tabular}

表 1 我が国におけるダイオキシン排出インベントリー 我が国におけるダイオキシン類排出量の推計（単位：g-TEQ/年)

\begin{tabular}{|c|c|c|c|c|}
\hline \multirow{2}{*}{ 発 生 源 } & \multicolumn{2}{|c|}{ 排 出 量 } & \multicolumn{2}{|c|}{ 考 } \\
\hline & 平成 9 年 (1997) & 平成10年 (1998) & 平成 9 年 & 平成10年 \\
\hline 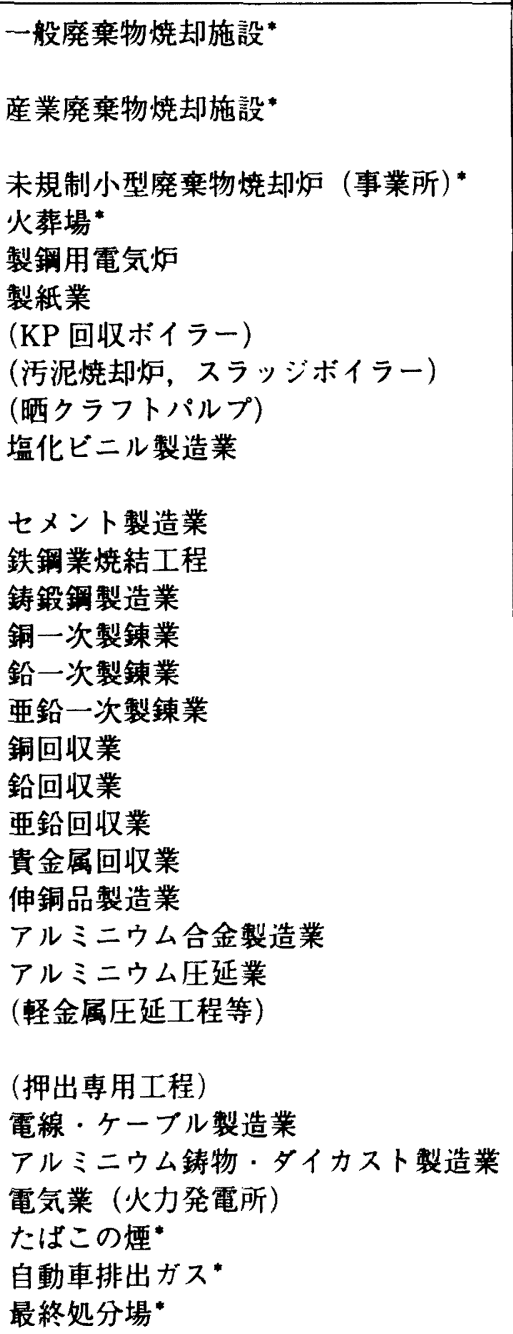 & 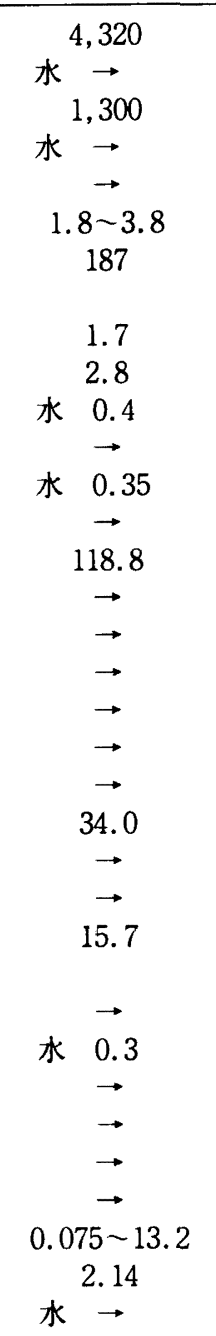 & 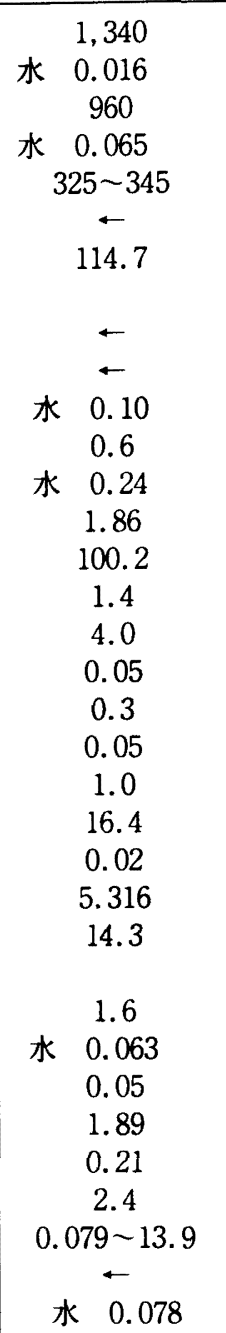 & $\begin{array}{l}\text { (1) } \\
\text { (6) } \\
\text { (5) } \\
\text { (2) } \\
\text { (2) } \\
\text { (2) } \\
\text { (2) } \\
\text { (3) } \\
\text { (3) }\end{array}$ & $\begin{array}{l}\text { (8) } \\
\text { (3) } \\
\text { (8) } \\
\text { (3) } \\
\text { (7) } \\
\text { (3) } \\
\text { (3) } \\
\text { (3) } \\
\text { (3) } \\
\text { (3) } \\
\text { (3) } \\
\text { (7) } \\
\text { (3) } \\
\text { (3) } \\
\text { (7) }\end{array}$ \\
\hline 計 & $6,330 \sim 6,370$ & $2,900-2,940$ & & \\
\hline
\end{tabular}

（注） 1：*印を付した発生源についてのデータは, 平成 11 年 6 月の環境庁「タイオキシン排出㧕制対策検 討会第二次報告」からの引用。

2 : 水への排出は実態調査結果のあるものについて掲載した。

3 : 排出量については, 無印のものは大気への排出を示す。

4 : 矢印は推計年と同様の排出があったとみなしたことを示す。

5 : 備考欄の番号は次に示す事項と対応する。
(1): 平成 9 年 1 月厚生省推計
(5): 平成 11 年 5 月厚生省推計
(2): 平成 9 年 5 月通商産業省推計
(6): 平成 11 年 6 月環境庁推計
(3): 平成 10 年 11 月通商産業省推計
(7): 平成 11 年 6 月通商産業省推計
(4): 平成 11 年 4 月厚生省推計
(8): 平成 11 年 6 月通商産業省, 環境庁推計 
ンが存在し，かつそれらと人類は付き合ってきたのだ。

\section{4. わが国におけるダイオキシン類の発生状況}

わが国としては, 今でも約 $2,900 \mathrm{~g} /$ 年 (平成 10 年 度）程度のダイオキシンを排出していると推定されて いる。注目すべきことは, 平成 9 年から 10 年までに 約半減していることである。これは廃棄物処理場から の排出量が激減したことによる。

産業界からの排出量は 9 年度の $6,000 \mathrm{~g}$ の内 $300 \mathrm{~g}$ 余りと大きくなく, 産業界の生産行為から排出される タイオキシンは全体に比べ1割ぐらいしかない。ま た, 10 年度も確実に減少してきているという状況であ る。過去にはかなり排出していたところもあったであ ろうが，業界が自主的に対策を取った成果であると聞 いている。特に製秖亲の場合には，平成 9 年よりも以 前には若干高い数字が出ていたといわれているが, 現 在は数 $\mathrm{g}$ というオーターまで下がってきているので, これは業界全体が積極的に努力をした成果だと考えて いる。これについては，われわれも高く評価しており， このような業界の自主的な取り組みが今回の排出規制 値などを決める祭には，大きな影箱を与えてきたので ある。

\section{5. ダイオキシン類対策特別措置法の概要}

第 1 条は目的等であり, 第 6 条は許容 1 日摄取量を 決めたものである。法律上では $4 \mathrm{pg}$ (ピコクラム) 以 下で政令で定めることになっている。許容 1 日摄取量 について WHO では, 1 4 pgで定めるべきたという

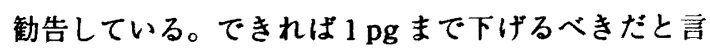
っているわけだが，WHOは現状を見つつ進めるべき たということも勧告していて，日本の数字もそれに習 ったものであるということが言える

第 7 条では，環境基準というものを設定することに なっている。境基準は大気, 水質（底質も含む）に ついて環境基準を作ることになっている。

実際には，大気の㻴境基準は, $0.6 \mathrm{pg} / \mathrm{Nm}^{3}$ という数 值になっている。これは平成 9 年 6 月に中央環境審議 会の大気部会がタイオキシン類の大気環境指針として 出した $0.8 \mathrm{pg}$ の 4 分の 3 程度の数字になっている。

排水の環境基準については, $1 \mathrm{pg} / l$ (ピコタラム パー・リットル)で, 東京ドームを满杯にした中に 1 グラムの角砂糖を 1 個入れた浱度である。

土壤の環境基华は $1,000 \mathrm{pg} / \mathrm{g}$ である。これには付 带条項が付いていて, $250 \mathrm{pg}$ を超えるとモニタリンク 等の調查を行うことになっているが, 250 という数字 は何ら法的根抛を持った数字ではない。
図 1 に示すように環境基準は, 大気, 水質, 土壤と いう三つについて決められている。また，排出ガスお よび排出水に関する規定としては，その規制の対象と なる特定施設を決めなければならない（第 2 条）。規 制の対象となる特定の排ガス関係施設としては, 通産 省関係の施設では製鋼用電気炬, 燒結装置, 亜鉛回収 装㯰及びアルミニウム合金施設の 4 つで, このほかに も廃棄物焼却炬が特定施設になっている。

また排水関係では，製紙業関係ではクラフトパルフ 製造用に供する施設として, 塩素系の漂白施設が対象 になっており，またその他の業界でも，アルミニウム またはアルミニウム合金の製造用に供する施設の中の 一部のものがある。また塩化ビニールモノマー製造用 に供する施設のうち 2 塩化エチレン洗浄装置等, 以上 3 施設が当省の関連施設である。この他に PCBの分 解施設及び関連洗浄装置, 廃萧物の燃焼施設の排ガス 洗浄装置等々, 水の関係は下水道の終末処理施設など も含めて特定施設として指定されている。

これらの特定施設についてその排出基準，つまりこ れ以上に出してはいけないという数字が決められてい る: また排ガスでは, 新設炉, 既設炉で各々基準が決 められており，例えば製銅用電気炉では新設で $0.5 \mathrm{ng}$ $\cdot \mathrm{Nm}^{3}$, 既設で $5 \mathrm{ng} \cdot \mathrm{Nm}^{3}$ である。この数字は, 鉄 鋼関係，いわゆる電気炉を持って製鋼を行っている人 たちが集まって作った自主的なガイドラインの数字を もう一度法律にオーバライトした数字である。したが って業界が自主的に対策を取りそれらを自分たちで守 っていくことを発表した数字が法律の規制值という形 で採用されたのである。

排ガス関連については，以上の数字になっており， 実際の適用は平成 14 年 12 月から, その前までは暫定 值が適用されることになっている。また廃棄物焼却炉 についても，廃棄物处理法の前は 1 時間当たり 4 トン 以上焼却できる炉, 2 トン〜 4 トン, 2 トン未満という 形で三つのカテコリーに分けて，新設炉，既設炉別に 数字を作っている。

また排水の排出基準については，施設の別なく 10 $\mathrm{pg} / /$ になっている。以上が排水基準についての第 8 条関係である。このほかにも第 10 条，大気の総量規 制基準がある。大気污染防止法の中にも総量規制の項 目があって，それを引用したものたが，環境基準の達 成が困難な場合は, ある特定の地域について総量削隇 計画を作成し，総量規制基準を設定することができる。 すなわち排水基準も従来の値よりも笅しいものになる が，そのようなことができることになっており，また 住民がこういう地域を設定するようにという形で都道 
府県の知事を経由して，国に意見の具申ができる制度 も作られている。

それから，特定施設の設置や変更の場合に届出が必 要となっている。特に法律が施行されたあと 1 力内内 に既成施設ついては届出を出すことになっていて,2 月 15 日までにすでに皆さんは関係のところに届出を されているものだと信頼している。

ただ，生産設備自体では正しく出ていると思うが， 廃棄物焼却炬を持っているところがあれば，これが本 当に対象となるのかならないのかということを，もう 一度工場に㷌ってこ確認をいただきたい。というのは， 廃掃法による規制対象となっている廃裹物焼却炬は, 下限值が $200 \mathrm{~kg} / \mathrm{hour}$ 以上の能力をもつものである。 しかし，今回のタイオキシン対策特別措置法の中で対 象としているのは, 廃裹物焼却炬は $50 \mathrm{~kg} /$ hour 以上 の能力を持つものとなっている。したがって 50〜200 $\mathrm{kg} / \mathrm{hour}$ の廃裹物烧却炉を持っているところは，廃掃 法上の手続きは必要ないが, タイオキシン対策特別措 置法上の手秸きは必要となっている。このことは去年 から，何度も言っているので耳にタコができたとおっ しゃられるかもしれないが, もう一度ご確認をいただ きたい。

3 月 31 日現在でタイイキシン類対策特別措置法上 の特定施設として届出た施設で廃棄物焼却炬は 2 万 2,511 になっている。事業者数では 20,518 , 施設数で は22,511になっており, $50 \mathrm{~kg} /$ hour 以上で $200 \mathrm{~kg} /$ hour 未满の廃裹物焼却炬は, その中の 14,000 程度で ある。6 割強の廃裹物焼却炬が $200 \mathrm{~kg} / \mathrm{hour}$ 未満であ る。廃棄物烧却炉についても，届出を確実に行ってい ただきたい。

また 24 条関係のばいじん，烧却灰中の䈨度基準と して, $3 \mathrm{ng} / \mathrm{g}$ という数字が厚生省で決められている。

土壤污染の関係，それから国の計画，33 条では国が 事業分野別の排水量の削減目標量とかそれらの措置の 計画を作成して出さなければならないことになってい るが、これはまだできていない。これからやることに なっている。

\section{6. 法律制定の経緯}

では。この法律の数字はどのように決められていっ たのかについて，若干裹話を含めて紹介したい。昨年 の 7 月以降, 環境庁の中央環境害境会で,タイオキシ ンのための準備が具体的に行われてきた。まず大気部 会には, タイオキシン類瑔境基涑専門委員会とタイオ キシン類排出規制専門委員会の二つの専門委員会が設

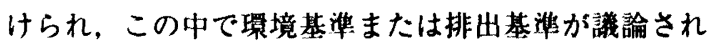

た。また特定施設をどのようにするかという議論もで なされた。また氷質部会の中にもタイオキシン類環境 基準専門委員会, ダイオキシン類排出規制専門委員会 の二つの専門委員会ができ, 環境基準, 排出基準拉よ び特定施設の制定について議論された。また土壤の部 会の中には, 従来の土壤の専門委員会を解散して土壤 専門委員会という名前に変え，そこで環境基準の議論 をしてきた。また廃棄物部会においても，以前からあ った専門委員会において, 最終処分の際の取扱いに関 する基準を作った。

\section{7. 外国の状況}

基準策定に際して最初にこれら専門部会で行ったの は，科学的な知見と実態デー夕の収集である。諸外国 でどのような规制をしているのか，または諸外国でど のような数字でやっているのかを勉強しないと作れな いということでいろいろと勉強した。大気などの場合 は，海外で環境基準を決めている国は世界中にはない ことが，㻴境庁の報告で明らかになった。欧米では夕 イオキシンに対して非常に大きな関心を持たれている とわれわれも認識していたわけだが，今回決めた環境 基準という形のものは海外に存在していないことが分 かった。またその排出基染についても，どの程度のも のが決められているのかを調べたのだが，明確な形で 法律に基づく排出基準の形で決められているものは極 めて少ないことが分かった。たとえばドイツの都市コ ミ焼却については, $0.1 \mathrm{ng} / \mathrm{Nm}^{3}$ という数字が決められ ているが，これは都市コミだけであり，それ以外のも のについてはガイドライン值はあるが, 排出基準值は ない。また米国などでも，新設のものについて 0.14 $\sim 0.21 \mathrm{ng} / \mathrm{Nm}^{3}$ という数值を都市コミ焼却に限って決 めているだけであったと報告されている。

つぎに水の環境基準，排出基準について述べる。ま ず米国の環境基準については，われわれがいま議論し ようとしているようなダイオキシン類全体を対象とす る基準はない。アメリカ環境省のクライテリアの中で は, $0.013 \mathrm{pg} / l$ という数字が挙げられているが,これ は前述のジベンソーパラージオキシン（2378）のみの数 字である。従って，われわれが言っている換算値では ないから, 0.013 という数字は低いように見えるが, われわれの值に比べて一概に大きい小さいと言うこと はできない。州によって違うが 0.013 というのは一番 低い数字である。ミネソタ州の場合は $20 \mathrm{pg} / l$ である。 全体的に換算值を使用しているところはあまり多くな い。

オランタでは換算値を使って，それもコプラナー 
PCB を含んだ值として $1 \mathrm{pg} / l$ である。これは飲料水 の基準ではなく地下水の基準である。また海外の排出 基準として, イタリアのガイドラインでは, 都市工業 排水で $0.5 \mathrm{pg} / l$ という数字があり,アメリカの製紙 工場では $30 \mathrm{pg} / l$ という数字がある。ただこれは規制 対象になっている工場は一つしかないと開いている。 対象となっている物質もジベンソーパラージオキシン (2378)だけと闁いている。このように世界では, 様々 な規制值が使用されており，またその数字についても 考え方がバラバラであることが分かってきている。 今年の 2 月に通産省は，アメリカやカナタのタイオ キシン分析の現状を調査するための調査団を出してい る。これによると, 彼らの分析, サンプリング等は極 めてシステマティックではあるが、日本人がやってい るほど気を付けてやっていないという。また，全体の パラージオキシン及びジベンソフフランとその異性体に ついて, 全部調へるような調査を行っていないことが 分かった。

次に通産省と㻴境庁は寒態の把握のため, 平成 11 年の 8 月から 9 月にかけて, 製紙業界にもお願いをし て調查をした。製紙業については箂合排水では全部で 32 ヶ所測定をさせていたたいた。32ヶ所の中で, 適 切な数値が得られたと評価できるデータでは，最大 $6.2 \mathrm{pg} / l$, 最小 $0.065 \mathrm{pg} / l$ であった。データを評価 した際に，信頼性について若干疑義のあるデータが出 てきた。これは去年の11月に環境庁が出された報告 書の中にもあるが, タイオキシンの泿度は測定者の個 人差とか測定の仕方によって 3 倍もの差が出るという ことであった。このときに総合排水の数字は，業界の 皆さんが独自にチェックした数字と比較をしてみると かなりの乘離があったのである

では，どのようにして良いものだけを振り分けたの か議論があるのだが，それはわれわれとしても専門家 に依頼をして異性体の分布等を手挂りに，他のものの 混入がないかどうかきちっと分析をし，異性体の分布 等から考えてこれは良さそうだというものだけを今回 使ったわけである。このような奉態調査をやり, 議論 を重ねていったわけである。11月までには前述のよ うな数字の案を作り, パブリック・コメントを求め, コメントへの回答を㻴境宁が作成し 12 月には正式に 決定をした。

\section{8. 大気, 土壤の環境基準, 排出基準}

大気や水質の排出基準を決める際にいろいろな論点 があったので，それについて一部ご紹介をしたい。ま ず大気では，前述のように環竟基染 $0.6 \mathrm{pg} / \mathrm{Nm}^{3}$ とい
う数字になったわけだが,これは前述のように平成 9 年 6 月 20 日に大気部会が出した数字の $0.8 \mathrm{pg}$ に比べ て 4 分の 3 になっている。この数值が決まるまでには つぎのような議論があった。環境におけるダイオキシ ンの浱度を環境庁が調べた結果, $0.8 \mathrm{pg}$ を超えている 地点はほとんどなかった。これは極めて良いことであ $\eta$ ，従来の基準の 0.8 がほとんどのところで満足され ているのならば, 0.8 でいいだろうと思っていた。し かし, 環境庁ではダイオキシン類も含めて有害物質は ゼロに近づけば近づくほどよいので，環境基準もなる べく低く押さえ込むべきという主張であった。私とし

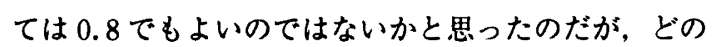
ぐらいの数字ならばいいのかを議論した。結局, 污染 の実態に基づき改善の必要な地点における対策が社会 的に過重な負担とならない数字に決められたのである。

排出基準の特定施設については, そもそも特定施設 の中に従来業界が自主的に対策を行ってきている施設 を含ませるべきかどうかという議論があった。法律を 作る際に製鋼用電気炬と廃菓物の焼却炬は, 法律の中 にも特定されており，ここはもう逃げられないと観念 をしていた。もう一つ従来対策を取ってきたところは， 大量のダイオキシンを出していることを自他ともに認 めているので, 法律ができてからそのようなところを 抜くことは対外的に問題があると判断をして, 業界が 自主的に取り扱っている 4 業種については妥協をお願 いし，一応やむを得ないとしてきたわけである。たた 前述のように業界が決めた数字が規制の中にそのまま 取り入れられたことは，産業界の自主的な取組が認め られたという意味で，非常に大きな成果ではなかった かと思っている。

\section{9. 水質の環境基準，排出基準}

水質については，議論は大気ほど簡単ではなくいろ いろと議論があったが詳細は省略する。論点としては, (1)水を通して出ているダイオキシンは $1 \%$ に満たな いのに排出の少ない水をなぜ规制するのかということ, (2)タイオキシン類の一番蕃積されているのは魚類であ ク, 魚類は水の中にいるわけだから, 水という媒体に 何らかの関係を持って蓄積が行われている。その過程 がどのようなものであるのかはまだ分っていないが, その過程を明らかにしたうえで数字を決めていくとい うのが, 本来の姿ではないか, (3)排出基準は，環境基 準の 10 倍にあたる $10 \mathrm{pg} /$ てで良いのか，等がある。

(2)については環境基準のときに同じような議論をし て, 水質の環境基準を決める先生方には，魚類から人 に入るタイオキシン類が一番多いわけだから，大気か 
ら水に入ってそれがどのような形で魚に蓄積されてい るかを全部明らかにした上で，数字を決めていくべき だと言っている先生方が多くいた。ただここの知見が 今のところはとんどないのである。従って大気からど れぐらいが水に落ちていくのかとか，水に溶けている ダイオキシンがどのような過程を経て水生生物に蓄皘 されていくのかということついては今後の課題に委ね られている。

\section{0. 環境基準}

それでは，どのようにして環境基準が決まったのか ということだが、これはTDI，前述した1日当たり の摄取量 $4 \mathrm{pg}$ という数字から逆算して導き出した数 字になっている。WHOは飲料水の水質ガイドライン を出しており，タイオキシンの場合はTDI の $10 \%$ を 割り当てることになっている。これにはある条件があ ク, 他の媒体を経由した暴露が大きい場合（日本の場 合は魚だが), TDIの $10 \%$ ではくて $1 \%$ な゙よ い,1\%を飲料水に割り当てればよいことになる。環 境庁はこの $1 \%$ という数字を使って, $4 \mathrm{pg}$ のうちの $1 \%$ を飲料水から取ると仮定をしたわけである。 $4 \times$ 0.01 という数字があり,これは 1 キロクラム当たり の数字だから, 成人の場合は $50 \mathrm{~kg}$ あると仮定して 50 倍をする。するとまず 2 という数字が出てくる。 これは 1 日当たり水から成人が搷取してもかまわない タイオキシンの量が $2 \mathrm{pg}$ という数字になる。通常 2 リットルの水を 1 日に飲むという仮定をおくと, $2 \div 2$ $=1$ となる。従って $1 \mathrm{pg} / \mathrm{l}$ という環境基準が導かれ たわけである。排出基泮や㻴境基泍を諳論する際は，
主により厳しくするほうの議論を中心に議論がなされ ていた。ただ環境庁は科学的な知見がないということ， これを行うことによって社会的影響が大きいというこ とを配慮して今のような数字になったわけである。

また，特定施設を最終的に決める際にも紆余曲折が あり，特にその対象となったのは皆さんの業界である。 クラフトパルプ製造業に供する施設のうち塩素系の漂 白施設にも，多イオキシンの発生の少ない方式として ECFがあるのではないかということであった。環境 庁は ECFという方式に対しての知見が今のところな いということで, 現在はそれを除外するだけの明確な 根拠がないから入れておかざるを得ないということで 対象となっている。しかし、ご存じのように皆さんの 業界と環境庁も入った形で ECFについてのタイオキ シンの発生について科学的な根拠を収集するとともに, 実証する試みをしており，ECFが夕イオキシンを発 生させないということが明確になった場合には, 特定 施設の見直しも行われると期待している。

\section{1.おわりに}

最後に指摘したいのだが, データの精度の問題が大 きな問題として浮き上がってきている。数值に 3 倍も の開きのあるものがある。またわれわれのほjのクロ スチェックでも，ひどいものは 1,000 倍を超えるよう な値の開きがあるということで, どうしてこのような 精度のばらつきが出るのかということを去年の 12 月 から勉強をしており，いま報告書のとりまとめをやっ てところである。 


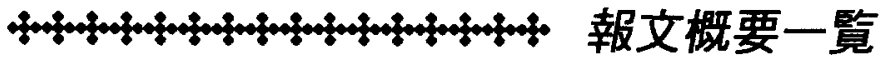

\section{環境会計ガイドラインと環境庁の取り組み}

琂境庁 企画調整局企画調整課調查企画室㻴境専門調查貝 小林 俊

環境庁は本年 5 月に新しい報告「㻴境会計システムの確立に向けて（2000 年報告）」を公表した。こ の報告は, 平成 11 年 3 月に公表した「環境保全コストの把㩧及び公表に関するガイドライン（中間と りまとめ)」を充実，発展させる形で取りまとめた「環境会計システムの導入のためのガイドライン $(2000$ 年版)」を主たる内容にとしている。㜊境会計とは, 企業や地方公共団体等の環境保全への取り組みを 可能な限り定量的に把挃し，分析し，公表する仕組みということができる。

本報では, 2000 年報告に対する桭境庁の取り組み, 環境会計システムの枠組み, 今後の方向等につい て概説する。

(本文 3 ページ)

\section{ダイオキシン類対策特別措置法及び関連法規の解説}

\section{通産省 環境立地局噮境指導室長 大滝 昌平}

タイオキシンは, 昨年所沢市で発生した問題を契機に社会問題と認識されるようになり，タイオキシ ンについて规制する必要があるとの詥議がなされた。その結果, 昨年 7 月に「タイオキシン類対策特別 措置法」が成立した。この法律では, 对象となるタイオキシン類として, 従来のタイオキシン（ボリ塩 化ジベンソーパラージオキシン) とボリ塩化ジベンソフランの 2 種類に加えてコプラナーポリ眚化ビフェ ニルを含めて定義している。

本報では，同法の成立の背褁，経緯，概要等について概観する。

(本文 13 ページ)

\section{環境アセスメント一概要と手続き—}

東レエンジニアリング株式会社 尾藤 武

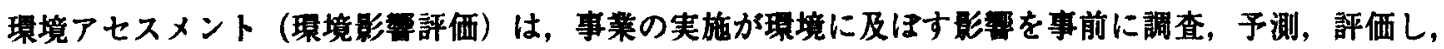

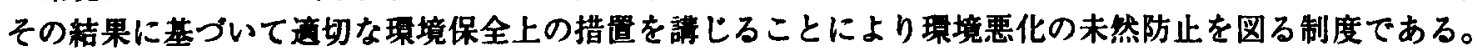

この制度の嗃用はもともと大規模な事業が対象であることから，これまで，工場の新設・增設の場合 を除いて企業の生産現場とはほとんと無関係と思われがちであった。しかしながら，近年，製紙業界に おいては古紙や製品余材の再凘源化等に伴い副次的に生じる廃棄物の処理のため, 自社内に処理施設を 設贯するケースが增加しており，その施設規模によっては地方自治体条例に基づく環境アセスメントが 必要となるほか, 小規模施設であっても 1997 年 6 月に改正された廃棄物処理法の規定により生活環境 影律調査の実施が必要となった。これにより，滗境アセスメントは今や企業の生産現場に直結して対応 すべき身近な課題の一つとなりつつある。

我が国では 1999 年 6 月より全国制度の根幹となるアセス法（棵境影鳘評価法）が施行され，これと 前後して大半の地方自治体の制度も改正が行われるなど, 環境アセスメントも新制度のもとで新たな歩 